\title{
Nonsteroidal anti-inflammatory agents in the treatment of asthma in children
}

\author{
PIERRE GAUDREAULT MD FRCPC \\ Department of Pediatrics, University of Montreal, and Clinical Pharmacology and Toxicology \\ Section and Emergency Medicine Service, Hôpital Sainte-Justine, Montréal, Québec
}

P GAUDREAULT. Nonsteroidal anti-inflammatory agents in the treatment of asthma in children. Can Respir J 1995;2(Suppl A):24A-31A.

The increasing scientific information clearly demonstrates the important role of inflammation in asthma. This evidence has led physicians to focus their treatment on the elimination of inflammation instead of working solely against bronchoconstriction. Steroids and nonsteroidal agents are currently used to prevent this inflammatory component. This paper focuses only on nonsteroidal inti-inflammatory agents such as sodium cromoglycate, nedocromil sodium and ketotifen and their use in pediatric asthma. The discussion on each medication addresses its mechanism of action, the cvidence concerning its efficacy in pediatries (ie, clinicul pharmacology, acute bronchial challenge, late asthmatic response, bronchial hyperreactivity, clinical efficacy) and the pediatric dos:

Key Words: Asthma. Chitdren. Nonsteroidal ant-inflummatory agents

\section{Les agents anti-inflammatoires non stéroïdiens dans le traitement de l'asthme chez l'enfant}

RÉSUMÉ : L’information scientifique croissante démontre clairement le rôle important de l'inflammation dans l'asthme. Cette évidence a conduit les médecins à orienter leur traitement vers l'élimination de l'inflammation au licu de se concentrer uniquement sur la bronchoconstriction. Les agents stéroïdiens et non stérö̈diens sont couramment utilisés pour prévenir cette composante inflammatoire. Cet article porte seulement sur les agents anti-inflammatoires non stéroïdiens tels que le cromoglycate de sodium, le nédocromil de sodium et le kétotifène ainsi que sur leur utilisation dans l'asthme pédiatrique. La discussion sur chaque médicament aborde son mécanisme d'action, des données concernant son efficacité en pédiatrie (par exemple, pharmacologie clinique, provocation bronchique aiguë, réponse asthmatique tardive, hyperréactivité bronchique. efficacité clinique) et la posologie pédiattrique.

\section{SODIUM CROMOGLYCATE}

Sodium cromoglycate was introduced in England for the treatment of asthma in 1968. It is a derivative of khellin. a furanochromone obtained from the Mediterranean plant Aimmi visnaga (Umbelliferae). In folk medicine, the seeds of this plant were used for their smooth muscle relaxant properties. Khellin derivatives in which the 2-mcthyl group has been replaced by a carboxylic acid moiety, as in sodium cromoglycate, have no bronchodilating properties; however. they can inhibit bronchoconstriction induced by inhalation challenge with antigen (1). Sodium cromoglycate is a white hydrated powder, highly polar, with a pKat of 2 and a molecular weight of about $500 \mathrm{Da}$. It can be administered from three different formulations: dry powder, solution for nebulization or metered dose inhaler.

\section{Mechanism of action}

The precise mechanism of action of sodium cromoglycate has not been completely elucidated. One of its primary modes of action is thought to be the stabilization of mast cells, which

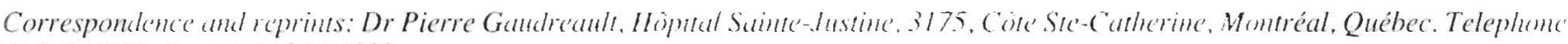
$(5 / 4) 345-4931 . \operatorname{lax}(5 / 4) 345-4822$ 
TABLE 1

Sodium cromoglycate $20 \mathrm{mg}$ qid effect on lung hyperreactivity in children

\begin{tabular}{|c|c|c|c|c|c|c|c|}
\hline Authors (reference) & $\mathbf{n}$ & Age (years) & Severity & Delivery system & Duration & Challenge & Effect \\
\hline $\begin{array}{l}\text { Dickson } 1970 \\
(17)^{*}\end{array}$ & 10 & 6-16 & Severe & Spincaps & 2-7 weeks & $\begin{array}{l}\text { Exercise } \\
\text { Histamine }\end{array}$ & $\begin{array}{l}+ \\
+\end{array}$ \\
\hline $\begin{array}{l}\text { Dickson } 1979 \\
(17)^{*}\end{array}$ & 50 & $3-16$ & Severe & Spincaps & 10 years & $\begin{array}{l}\text { Exercise } \\
\text { Histamine }\end{array}$ & - \\
\hline $\begin{array}{l}\text { Furukawa et al } 1984 \\
\text { (85) }\end{array}$ & 46 & $5-15$ & Mild/moderate & Spincaps & 12 weeks & Methacholine & + \\
\hline $\begin{array}{l}\text { Kraemer et al } 1984 \\
\text { (86) }\end{array}$ & 32 & $5-17$ & & Nebuliser & 8 weeks & Carbachol & + \\
\hline $\begin{array}{l}\text { Shapiro et al } 1988 \\
(87)\end{array}$ & 27 & $6-12$ & Mild/moderate & Nebuliser & 8 weeks & Histamine & + \\
\hline $\begin{array}{l}\text { Watanabe } 1988 \\
(17)^{*}\end{array}$ & 34 & $6-16$ & Moderate/severe & Spincaps & 3 years & Histamine & + \\
\hline
\end{tabular}

Data adapted from reference 17. "Cited in reference 17. + Decrease effect; - No effect

prevents the subsequent relaise of mediators. Sodium cromoglycate inhibits mast cell degranulation produced by inmunoglobulin $\mathrm{E}$ antibody reactions, phospholipase $\mathrm{A}$, compound 48/80, and the calcium ionophore A 23187 (2-4). This mast cell membrane stabilization appears to be relatted to the phosphorylation of a membrane protein that can modulate calcium intracellular influx (5). Other modes of action involve the reduction of bronchoconstriction by an action on the afferent am of the nervous reflexes and the reduction in the activity of lung irritant receptors and the inhibition of $\mathrm{C}$ fibre nerve endings (0).

The increasing emphasis on the inflammatory component of airway obstruction and its relationship with bronchial hyperreactivity has led to the study of sodium cromoglycate in models involving inflammatory cells. The administration of sodium cromoglycate can prevent the activation of peripheral blood neutrophik and cosinophils following immunological and nonimmunological stimuli $(7,8)$. Others have shown that its prolonged administration has resulted in a significant decrease of eosinophils in bronchoalveolar lavage fluids (9). This potential of sodiun cromoglycate to reduce inflammation may be more important than its mast cell stabilization in regard to its antiasthmatic effect.

Sodium cromoglycalte hats no intrinsic bronchodilator properties. In vitro, it reduces the contraction of smooth muscle induced by acetylcholine, histamine, serotonin, bradykinin, and prostaglandin (PG) $F_{2}$. Furthemore, it potentiates smooth muscle relaxition induced by isoproterenol, adrenaline, $\mathrm{PGE}_{2}$ and salbutanol (1). In vivo, sodium cromoglycate inhibits bronchoconstriction produced by exercise, the inhalation of cold air, sulphur dioxide, the nebulization of distilled water and leukotriene $\left.\mathrm{D}_{4}(6,10)-15\right)$.

\section{Clinical pharmacology}

Acute bronchial challenge: The administration of sodium cromoglycate can prevent the immediate and late asthmatic response to antigen challenge. Altounyan (16) demonstrated that the administration of sodium cromoglycate before an antigen challenge inhibited the fall in forced expiratory volume in I $s\left(F E V_{1}\right)$. This protective cffect diminished, however. when sodium cromoglycate was given after the antigen challenge. Furthermore, this protective effect of sodium cromoglycate lessened when the time between its inhalation and antigen challenge was increased (16). Although results on sodium cromoglycate's protective effect against constricting agents such as methacholine and histamine are conflicting (1), most studies have demonstrated its efficacy against numerous bronchoconstricting agents such as carbachol, sulphur dioxide, metabisulphite, exercise and cold air (1).

Late asthmatic response: Many asthmatics undergo a second bronchoconstrictive response 4 to $12 \mathrm{~h}$ following inhalation challenge with antigen. This phenomenon is known as the delayed or late asthmatic response. Sodium cromoglycate also blocks this late asthmatic response when given before challenge with a variety of antigens. Since the late asthmatic response is associated with severe asthma and correlates with increased bronchial hyperreactivity, some authors feel that the role of sodium cromoglycate in preventing this late reaction may be one of the keys to its ability to control and improve chronic asthma.

Bronchial hyperreactivity: Airway hyperreactivity is a characteristic feature of asthma and the degree of bronchial responsiveness, as measured by histamine challenge, has been shown to correlate with the severity of asthma. Despite some conflicting results, most studies have demonstrated that long term administration of sodium cromoglycate can reduce bronchial hyperreactivity in both adults and children (17). The results of several pediatric studies are presented in Table 1.

Clinical efficacy: Several studies have investigated the efficacy of sodium cromoglycate in the treatment of asthma (17). In pediatric studies, sodium cromoglycate was shown to be superior to placebo in improving pulmonary function tests and in reducing asthmatic symptoms, physician assessed isthma severity and concomitant bronchodilator use (beta2agonists and theophylline) (18-20). The amount of sodium cromoglycate deposited in the lung and subsequently adsorbed depends upon the dose administered, the delivery system and the proper technique. There is no direct correlation. however, between clinical efficacy and either the amount of drug deposited in the lung or cromolyn blood concentratlions ( 1 ). 
TABLE 2

Sodium cromoglycate versus theophylline

\begin{tabular}{|c|c|c|c|c|c|c|}
\hline Authors (reference) & $\mathrm{N}$ & Age (years) & $\begin{array}{l}\text { Symptom } \\
\text { control }\end{array}$ & $\begin{array}{c}\text { PFT } \\
\text { improvement }\end{array}$ & $\begin{array}{c}\text { Bronchodilators } \\
\text { prn }\end{array}$ & $\begin{array}{l}\text { Adverse } \\
\text { effects }\end{array}$ \\
\hline Hambelton et al $1977(88)$ & 28 & Children & $C<T=(C+T)$ & $\begin{array}{c}C=T \\
C<(C+T) \\
T=(C+T)\end{array}$ & $\mathrm{C}=\mathrm{T}=(\mathrm{C}+\mathrm{T})$ & $\mathrm{C}=\mathrm{T}=(\mathrm{C}+\mathrm{T})$ \\
\hline Edmunds et al 1980 (89) & 30 & $5-15$ & $P<T<C$ & $P<T=C$ & $P<(T+C)$ & $\mathrm{P}=\mathrm{T}=\mathrm{C}$ \\
\hline Glass et al $1981(90)$ & 16 & $2-4$ & $P<T=C$ & ND & $P=T=C$ & $\mathrm{P}=\mathrm{C}<\mathrm{T}$ \\
\hline Newth et al $1982(91)$ & 26 & $1-6$ & $T<C=(C+T)$ & ND & $\mathrm{T}=\mathrm{C}<(\mathrm{C}+\mathrm{T})$ & $\mathrm{C}<\mathrm{T}=(\mathrm{C}+\mathrm{T})$ \\
\hline Springer et al 1985 (93) & 13 & $8-13$ & $\mathrm{~T}=\mathrm{C}$ & $\mathrm{T}=\mathrm{C}$ & $\mathrm{T}=\mathrm{C}$ & $T=C$ \\
\hline
\end{tabular}

Data adapted from reference 1 . \& Not as effective; $B$ Baseline, C Cromolyn sodium; ND No difference; P Placebo; PFT Puimonary function tests: prn Used as required; Theophylline

Sodium cromoglycate has also been compared with other medications such as theophylline and steroids in the treatment of asthma. Some of the compurative studies between sodium cromoglycate and thcophylline that were pertormed in children are summarized in Table 2 (1).

These studies clearly demonstrate that sodium cromoglycalte and theophylline are equatly efficacious in the control of asthma symptoms and in improving pulmonary function tests; however, theophylline caused more gastrointestinal and central nervous system side effects. In adddition, sodium cromoglycate has an advantage over theophylline for long term use because of its ability to decrease bronchial hyperreactivity.

Both theophylline and sodium cromoglycate inhibit exercise-induced asthma but are less efficacious than beta2adrenergic agents. Sodium cromoglycate should be selected over these agents if a patient requires their use more than two to three times a weeh.

Early clinical studies of steroid dependent asthmatic patients suggested that the addition of sodium cromoglycate could have a corticosteroid sparing effect $(21,22)$. More recent data, however, could not confirm these results and were not able to demonstrate any benefit from combined sodium cromoglycate and corticosteroid therapy (23-25). Based on these results. there appears to be no advantage in prescribing sodium cromoglycate to steroid dependent patients.

\section{Pediatric dose}

Sodium cromoglycate is available in Canada in three forms - $20 \mathrm{mg}$ powdered capsule delivered via the Spinhaler (Fisons) apparatus, $1 \%$ solution containing $20 \mathrm{mg}$ of sodium cromoglycate per $2 \mathrm{~mL}$ of distilled water delivered by a compressor-driven nebulizer, and a pressurized metereddose inhaler that releases 1 mg per actuation.

No pediatric study has been donc to evaluate a possible dose-response effect for sodium cromoglycate; those carried out only compared single doses administered with different apparatus. In one study (26), $2 \mathrm{mg}$ doses of sodium cromoglycate administered via metered dose inhaler and $20 \mathrm{mg}$ administered via a Spinhaler apparatus were both efficacious in preventing exercise-induced asthma. In another study (27), doses of $2 \mathrm{mg}$ sodium cromoglycate administered yid vial metered dose inhaler and $20 \mathrm{mg}$ administered cid vial at
Spinhaler apparatus were equally elficacious in controlling chronic asthma symptoms. Carrasco and Sepulveda (28) noted, however, that although beneficial effects of sodium cromoglycate were equivalent at the end of the study period, they appeared sooner in patients receiving 10 my cid via metered dose inhaler instead of 2 my yid via metered dose inhaler.

Results from adult studies on dose-response effects are conflicting (17). Differences noted in adults can be partially explained by the fact that a dose-response effect seems to depend on the type of stimuli used to induce bronchospasm. For example, Tullet et al (29) demonstrated that $20 \mathrm{mg}$ of sodium cromoglycate administered with a metered dose inhaler was more efficacious than $2 \mathrm{mg}$ to prevent exerciseinduced asthma. In contrast, Latimer et al (.30) noted that doses of 2, 10 and $20 \mathrm{mg}$ all administered via a metered dose inhaler offered a protection against bronchoconstriction following inhalation of cold air similar to the one obtained with $20 \mathrm{mg}$ of sodium cromoglycate given with a Spinhaler.

Some authors have demonstrated that the duration of the effect of sodium cromoglycate is partially related to the amount given and the type of challenge stimulus used. Patel and Kerr (3I) noted that doses of $20 \mathrm{mg}$ and $40 \mathrm{mg}$ of sodium cromoglycate continued to provide a partial protection against an exercise-induced fall in FEV $27($ ) mins after their administration, whereas the effect of $2 \mathrm{mg}$ had worn ofl.

Several clinicians feel that the European formulition of $5 \mathrm{mg}$ of sodium cromoglycate delivered by a metered dose inhaler is more efficacious that the $1 \mathrm{mg}$ available in North America. There are no pediatric studies, however, to support that contention.

Sodium cromoglycate is very safe. The median parenteral lethal dose for different animal species is $4000 \mathrm{mg} / \mathrm{kg}$ ( I ). The inhalation route is even safer (I). Indeed, numerous studies involving mammals could not achicve lethal doses of sodium cromoglycate. Sodium cromoglycate produces no ill effect on normal immunological reactions, mucociliary activity or lung surface active properties and has no mutagenic or teratogenic effect. Side effects from sodium cronoglycatc are rare.

Based on data available in the literature, most patients should be adequately treated with the recommended dose of 
TABLE 3

Effect of nedocromil sodium on exercise-induced asthma in children

\begin{tabular}{|c|c|c|c|c|c|}
\hline Authors (reference) & $\mathbf{n}$ & Age (years) & Dose & Pulmonary function tests & Results \\
\hline Bauer $1986(43)$ & 10 & $12-16$ & $4 \mathrm{mg}$ (30 min pretest) & Specific airway conductance & $N>P$ \\
\hline Henrickson 1986 (32) & 12 & $7-14$ & $4 \mathrm{mg}$ (30 min pretest) & FEV $_{1}$, PEFR & $\mathrm{N}>\mathrm{P}$ \\
\hline Chudry et al 1987 (44) & 12 & $8-15$ & $4 \mathrm{mg}(30+150$ mins pretest) & $\mathrm{FEV}_{1}$ & $N>P$ \\
\hline Boner et al 1989 (45) & 20 & $7.5-15$ & 4 mg (30 min pretest) & $\begin{array}{c}\mathrm{FEV}_{1,} \text { PEFR } \\
\mathrm{FEF}_{25-75}\end{array}$ & $\begin{array}{l}N \cdot P \\
N=P\end{array}$ \\
\hline Comis 1993 (46) & 12 & $6.6-13.5$ & $\mathrm{C}: 4 \mathrm{mg}, \mathrm{N}: 10 \mathrm{mg}$ (30 min pretest) & FEV 1 & $\mathrm{~N}=\mathrm{C}>\mathrm{P}$ \\
\hline
\end{tabular}

$>$ More effective; $C$ Sodium cromoglycate; $F E F_{25-75}$ Forced expiratory flow rate at 25 to $75 \%$ of forced vital capacity; FEV $F_{0}$ orced expiratory volume in $t s ; N$ Nedocromil sodium; P Placebo: PEFR Peak expiratory flow rate

$2 \mathrm{mg}$ qid administered with a metered dose inhaler, or $20 \mathrm{mg}$ solution for nebulization or $20 \mathrm{mg}$ powder for the Spinhaler qid. When the patient is stabilised, these doses can be tapered to bid.

\section{NEDOCROMIL SODIUM}

Nedocromil sodium is the disodium salt of a pyranoyumoline dicarboxylic acid (32). Nedocromil sodium is a pale yellow powder, hydrophilic with a molecular weight of 415 . Following inhalation of nedocromil sodium in healthy volunteers, plasma concentrations risc rapidly and mean peak levels are reached in 20 mins, whereupon they plateau for $1 \mathrm{~h}$ followed by a declinc in plasma kevels. These plasma levels suggest the persistence of nedocromil in the lungs for a longer period than would be expected and maty account for therapeutic efficicy with a twice daily regimen (33).

\section{Mechanism of action}

Nedocromil sodium is a cromolyn-like agent with antiatlergic and anti-inflammatory properties. In animals. nedocromil sodium was able to inhibit partially bronchoconstriction induced by bradykinin, which is partially related to an inhibition of the axonal rellex, and other specific antigens such as ascaris in the ascaris-sensitive Macace arctoides monkey (34).

In vitio studies hatve shown that nedocromil sodium is at more potent inhibitor than sodium cromoglycate in the release of histamine, leukotriene $\mathrm{C}_{4}$ and prostaglandin $\mathrm{D}_{2}$ in primate lung mast cells, and of hist:mine in human mast cells (35.36). It can also prevent chemotactic and inflammatory mediator release from aninal derived eflector cells such as granulocytes, monocytes, macrophages, cosinophils, platelets and mast cells $(37,38)$.

\section{Clinical pharmacology}

Acute and late bronchial challenge: Results from numerous adult studies have demonstrated that nedocromil can prevent hronchospasm induced by exercise, fog, cold air, adenosine, sulphur dioxide and antigen (32,39-42). Moreover, it was also more efficacious than sodium cromoglycate in these studies. In pediatrics there is a paucity of such studies. However, the few studies conducted on this subject demonstrate that nedocromil was also able to prevent exercise-induced asthma in chikiren (Table 3) (32,43-46). In one pediatric study where nedocromil sodium efficaly in the prevention of exercise-induced asthma wats compared with sodium cromoglycate efficacy, both treatments produced a similar response (46). Similar to sodium cromoglycate, nedocromil sodium can inhibit the late bronchoconstrictor response to allergen challenge (47).

Bronchial hyperreactivity: Airway hyperreactivity com monly occurs following antigen exposure during the pollen season. Studies in adults have shown that nedocromil sodium can significantly decrease bronchial hyperactivity $(48,49)$.

Clinical efficacy: Numerous studies in adults have investigated the efficacy of nedocromil sodium in the treatment of asthma. Recently, Edwards and Stevens (50) published a meta-analysis of all known placebo controlled, double-blind, randomized therapeutic trials. Overall, their meta-analysis demonstrated that nedocromil sodium decreased the use of inhaled bronchodilators, reduced day-and nighttime symptoms of asthma and improved pulmonary function tests such as mean daily peak expiratory flow rate and FEV $(50)$. Preliminary studies in children reported an improvement in lung function and a decrease in bronchodilator requirements during the administration of nedocromil sodium (32). Studics in adults on the steroid sparing effect of nedocromil have generated conflicting data (51-54). Such data are not available in pediatrics.

In vitro and adult studies suggest that nedocromil sodium is a more potent anti-inflammatory and antiasthmatic agent than sodium cromoglycate $(32,35,36,39-42)$. There are no data in the pediatric literature to confirm or refute that conclusion. In the absence of this information it is difficult to determine the exact role and place of nedocromil sodium in the treatment of asthma in children.

\section{Pediatric dose}

Nedocromil sodium is only available in a metered dose inhaler formulation. There is no dose-response effect for nedocromil sodium in children. The recommended dose is $4 \mathrm{mg}$ qid. When the patient is stabilized, this dose can he tapered to bid (32).

\section{KETOTIFEN}

Ketotilen is a benzocycloheptathiophen derivative with antiallergic and antianaphylaktic properties. Ketotilen is rapidly absorbed following oral administration, and peak plasma levels are reached within $210 \neq \mathrm{h}$. There is no established correlation between ketotifen blood concentration and its 
TABLE 4

Efficacy of ketotifen on asthma in children

\begin{tabular}{|c|c|c|c|c|c|}
\hline Authors (reference) & $\mathrm{N}$ & Age & Dose & $\begin{array}{l}\text { Bronchodilator use/ } \\
\text { symptoms }\end{array}$ & Results \\
\hline $\begin{array}{l}\text { Lopez } 1985 \\
\quad(67)\end{array}$ & 60 & $1-15$ years & $0.5-2 \mathrm{mg} / \mathrm{day} \geq 12$ weeks & $\begin{array}{l}\text { Symptoms } \downarrow \\
\text { Bronchodilators } \downarrow\end{array}$ & $\begin{array}{l}K>P \\
K>P\end{array}$ \\
\hline $\begin{array}{l}\text { Miraglia et al } 1986 \\
\text { (69) }\end{array}$ & 33 & 3 years & $0.1 \mathrm{mg} / \mathrm{kg} 12$ weeks & $\begin{array}{l}\text { Symptoms ! } \\
\text { Bronchodilators } \downarrow\end{array}$ & $\begin{array}{l}K>P \\
K>P\end{array}$ \\
\hline $\begin{array}{l}\text { Koh et al } 1988 \\
(71)\end{array}$ & 30 & 3-11 years & $0.03 \mathrm{mg} / \mathrm{kg}$ bid 12 weeks & $\begin{array}{l}\text { Symptoms } \downarrow \\
\text { Bronchodilators! }\end{array}$ & $\begin{array}{l}K>P \\
K>P\end{array}$ \\
\hline $\begin{array}{l}\text { Neijens and Knol } 1988 \\
(72)\end{array}$ & 134 & $<4$ years & $0.5 \mathrm{mg}$ bid 12 weeks & $\begin{array}{l}\text { Symptoms } \downarrow \\
\text { Bronchodilators } \downarrow\end{array}$ & $\begin{array}{l}K>P \\
K>P\end{array}$ \\
\hline $\begin{array}{l}\text { Naspitz and Fiere } 1988 \\
(73)\end{array}$ & 75 & 8 years (mean) & $1 \mathrm{mg}$ bid 20 weeks & $\begin{array}{l}\text { Symptoms }{ }^{\dagger} \downarrow \\
\text { Bronchoditators } \downarrow\end{array}$ & $\begin{array}{l}K \rightarrow P \\
K: P\end{array}$ \\
\hline $\begin{array}{l}\text { Dawson et al } 1989 \\
\text { (76) }\end{array}$ & 60 & $5-13$ years & $1 \mathrm{mg}$ bid 22 weeks & $\begin{array}{l}\text { Symptoms } \\
\text { FEV }_{1}, \text { PEF }^{*}\end{array}$ & $\begin{array}{l}\mathrm{K}>\mathrm{P} \\
\mathrm{K}=\mathrm{P}\end{array}$ \\
\hline $\begin{array}{l}\text { Groggins et al } 1980 \\
(77)\end{array}$ & 23 & $1-5$ years & $0.25-0.5 \mathrm{mg}$ bid 8 weeks & $\begin{array}{l}\text { Symptoms* } \\
\text { Bronchodilators }\end{array}$ & $\begin{array}{l}K=P \\
K=P\end{array}$ \\
\hline $\begin{array}{l}\text { Loftus and Price } 1987 \\
\text { (78) }\end{array}$ & 47 & $2-6$ years & $1 \mathrm{mg}$ bid 24 weeks & $\begin{array}{l}\text { Symptoms* } \\
\text { Bronchodilators }\end{array}$ & $\begin{array}{l}K=P \\
K=P\end{array}$ \\
\hline $\begin{array}{l}\text { Volovitz et al } 1988 \\
\text { (79) }\end{array}$ & 30 & $1-3$ years & $1 \mathrm{mg}$ bid 12 weeks & $\begin{array}{l}\text { Symptoms* } \\
\text { Bronchodilators* }\end{array}$ & $\begin{array}{l}K=P \\
K=P\end{array}$ \\
\hline $\begin{array}{l}\text { White et al } 1988 \\
(80)\end{array}$ & 37 & $1-6$ years & $\begin{array}{l}\text { I mg bid ( }<5 \text { years) } \\
2 \mathrm{mg} \text { bid ( } \geq 5 \text { years) }\end{array}$ & Symptorns $\downarrow$ & $K=P$ \\
\hline
\end{tabular}

$\downarrow$ Decrease in symptoms andior bronchodilator use: ${ }^{\star}$ No changes; ${ }^{\dagger}$ One of five symptoms were ameliorated; ${ }^{\ddagger}$ Two of four symptoms were ameliorated: > More effective; FEV, Forced expiratory volume in $1 \mathrm{~s}$ : K Ketotifen; P Placebo; PEF Peak expiratory flow

antiasthmatic effect. Its bioavailability is only $50 \%$ due to a 'first pass' effect. Ketotifen is extensively biotransformed and 60 to $70 \%$ of a dose of hetotifen is eliminated in the urine within 48 h (.55).

\section{Mechanism of action}

Our knowledge on ketotifen's mechanism of action is limited and presently under investigation. Experimental evidence suggests antianaphylactic properties substantiated by ketotifen's ability to inhibit the release of mediators of aniphylax is such as the stow reacting substance of anaphylaxis, and the inhibition of calcium uptake in isolated mast cells and in smooth muscle (50-58). In aninal models of passive cutineous anaphylaxis, ketotifen inhibits both passive cutaneous anaphylaxis and histamine-induced reactions $(56,57)$.

Ketotifen also exhibits some antiasthmatic properties. In animal studies ketotifen adnumistration before aerosol chatlenge attenuated bronchoalveolar eosinophilia (59). Eosinophil recruitment in the tracheobronchial tree and their activation within the lung releases cytotoxic proteins and potent inflammatory mediators (leukotriene $\mathrm{C}_{4}$, superoxide $\left[\mathrm{O}_{2}\right]$, platelet-activating factor) that will precipitate a calscade of events that will subsequently lead to bronchial hyper- reactivity $(55,60)$. Although ketotifen has no bronchodilator properties, it appears to be capable of increasing both the affinity for the beta2-adrenergic receptors and CAMP intracellular concentrations (55).

\section{Clinical pharmacology}

Acute bronchial challenge: Ketotifen administration has been shown 10 inhibit the bronchoconstriction caused by either histamine or allergen challenge but will not prevent bronchospasm induced by either methacholine inhalation or exercise $(55,61-64)$. Although the number of studies on acute bronchial challenge in children is very limited, they generated results similar to those obtained in adults $(55,65)$.

Clinical efficacy: Studies designed to evaluate the efficacy of ketotifen in the treatment of asthma in children have generated conflicting results (66-81). The parameters used to evaluate the efficacy of ketotifen in the treatment of asthma were mainly based on analysis of patients' symptom diaries and bronchodilator requirements. The majority $(66 \%)$ of the studies (Table 4) reported a decrease in both frequency of symptoms and use of bronchodilators, such as theophylline or beta2-agonists, in patients receiving oral ketotifen. These improvements occurred in most instances following long 
term administration (ic, more than eight weeks). In general, children responding to ketotifen experienced fewer interruptions of their daytime activities and fewer nighttime symptoms $(71,74)$. The majority of patients or their parents favoured ketotifen over placebo in their global assessment of the trial.

The information on the effect of long term ketotifen therapy on spirometric measures of airway obstruction is limited. In one study ketotifen tratment did not improve forced expiratory flow rate at 25 to $75 \%$ of forced vital capacity (FVC), but increases in FEV 1 and FVC reached statistical significance after six and 10 weeks of ketotifen therapy, respectively (75). In several studies, ketotifen treatment was not associated with improvement of peak expiratory flow rates $(74.76,80)$.

There are few studies comparing ketotifen with sodiun cromoglycate and none with nedocromil sodium $(82,83)$. In studies where sodium cromoglycate and ketotifen were administered conconitantly, the addition of ketotifen did not provide any additional benefit to the patient's treatment $(55,76)$. In studies comparing ketotifen with sodium cromoglycate, the two drugs produced similar improvement in asthma symptoms $(82,83)$.

Ketotifen prophylaxis to prevent the development of asthma in selccted infints and young children has been evaluated $(55,84)$. likura et al $(84)$ evaluated the prophylactic effect of ketotifen against the onset of asthma in 121 infants with atopic dermatitis without any history suggestive of asthma. Sixty-one patients received ketotifen $10.8 \mathrm{mg}$ for children weighing less than $14 \mathrm{~kg}$, and $1.2 \mathrm{mg}$ for children weighing $14 \mathrm{~kg}$ or more). During the one-year study period, asthma was observed in eight children from the ketotifen group $(13.1 \%)$ and in 25 children from the placebo group $(41.6 \%)(\mathrm{P}<0.001)$. Although the results of this study are very interesting, further investigations are required before broad use of ketotifen in atopic children can be recommended to prevent the development of asthmat.

Ketotifen is gencrally well tolerated, and the most com mon side effects are weight gain of 2.8 to $3.3 \mathrm{~kg}$ over a one-year period in children less than 12 years of age and drowsiness, which declines over one to two weeks $(55)$.

\section{Pediatric dose}

Children between six months and three years of age should be administered $0.5 \mathrm{mg}$ of ketotifen t wice daily, while I mg should be given to those over three years of age (55).

\section{CONCLUSION}

Nonsteroidal anti-inflammatory agents clearly have a role to play in pediatric asthma. Sodium cromoglycate and nedocromil sodium are two eflicicacious antiasthmatic agents that should be used in the treatment of chronic mild to moderate asthma. Several in vitro and adult studies suggest that nedocromil sodium seems to be more potent than sodium cromoglycate; however, similar data are lacking in the pediatric population. Therefore. hased on the information available in the pediatric literature, sodium cromoglycate could be the agent of first choice, but nedocromil sodium is certainly at very acceptable alternative.

Sodium cromoglycate and nedocromil sodium can prevent excrcise-induced asthma but are less efficacious than beta2-adrenoreceptor agents. They should be fivoured, however, in paticnts requiring more than one or two treatments per week.

The optimal pediatric dose of nedocromil sodium seems (1) be $4 \mathrm{mg}$ qid. Although the administration of $20 \mathrm{mg}$ of sodium cromoglycate via a Spinhaler apparatus or by nebulization qid is adequate, $2 \mathrm{mg}$ of sodium cromoglycate administered with a metered dose inhaler qid may not be optimal for all patients.

Since sodium cromoglycate is as efficacious as theophylline and produces significantly fewer side effects, it should be favoured in the treatment of the chronic asthmatic requiring one of these two medications.

The precise role of ketotifen in the treatment of mild chronic asthma remains to be determined. Its role in the 'early' prevention' of the development of asthma nerits funther investigations.

\section{REFERENCES}

I. Murphy S, Kelly WH. Cromolyn sodium: a review of mechanisms and clinical use in asthma. Drug Intell Clin Phatm 1987;21:22-35.

2. Orr TSC, Cox JSG. Disodium cromoglycate: an inhibitor of mast cell degranulation and histamine release induced by phospholipase A. Nature 1969;223:197-8.

3. Orr TSC, Hall DE, Gwilliam J, Cox JSG. The effect of disodium cromoglycate on the release of histamine and degranulation of rat mast cells induced by compound $48 / 80$. Life Sci 1971;10:805-12.

4. Johnson HG, Bach MK. Prevention of calcium ionophore-induced release of histamine in rat mast cells by disodium cromoglycate. J Immunol 1975; 1 14:514-6.

5. Spataro AC, Bosman HB. Mechanism of action of disodium cromoglycate mast cell calcium ion influx after histamine releasing stimulus. Biochem Pharmacol 1976:25:505-10.

6. Dixon M, Jackson DM, Richards IM. The action of sodium cromoglycate on ' $\mathrm{C}$ ' fibre endings in dog lung. $\mathrm{Br} \mathrm{J}$ Pharmacol 1980;70:11-3.

7. Moqbel R, Durham SR, Carroll M, et al. Enhanced neutrophy and monocytotoxicity after exercise-induced asthma. Thorax $1985 ; 40: 218-9$

8. Basran GS, Page CT, Paul W, Morel J. Cromoglycate inhibits the responses to platelet-activating factor (PAF-Acether) in man: an alternative mode of action for DSCG in asthma? Eur I Pharniacol 1983;86:143-4.

9. Flint KC, Leung KBP, Pearce FL, Hudspith BN, Brostoff J. Johnson NM. Human mast cells recovered by bronchoalveolar lavage: their morphology, histamine release and the effects of sodium cromoglycate. Clin Sci 1985;68:427-35.

1(1. Horn CR, Jones RM, Lee D, Brennan SR. Bronchodilator effect of disodium cromoglycate administered as a dry powder in exercise-induced asthma. Br J Pharmacol 1984; 18:798-80 I.

11. Ben-Dov I, Bar-Yishay B, Godfrey S. Heterogeneity in the response of asthmatic patients to preexercise treatment with cromolyn sodium. Am Rev Respir Dis 1983;127:113-6.

12. Fanta CH, McFadden ER, Ingram RH. Effects of cromolyn sodium on the response to respiratory heat loss in normal subjects. Am Rev Respir Dis 1981;123:161-4.

13. Sheppard D, Nadel JS, Boushey HA. Inhibition of sulfur dioxide-induced bronchoconstriction by disodium 
(romoglycate in asthmalic subjects. Am Rev Respir I) is I981;124:257-9.

14. Fuller RW, Collicr JC. Sodium cromoglycate and atropine block the fall in FEV, but not the cough induced by hyponomic mist. Thorax 1084:30:760-70).

15. Advenier C, Cerrina J, Dukroux P, et al. Sodium cromoglycille. verapamil and nicardipine antagonism to leukotriene $\mathrm{D}_{4}$ bronchoconstriction. Br J Pharmacol 1983;78:30 I-6.

16. Altounyan REC. Inhibition of experimental asthma by a new compound - disodiun cromoglycate (Intal). Acra Allergel 1967;22:487-9.

17. Hoag JE, McFadden ER Jr. Long-term effect of cromolyn sodium on nonspecific bronchial hyperresponsiveness: a review. Ann Allergy 1991:60:53-63.

18. Hiller EJ, Milner AD, Lenncy W. Nebulized sodium cromoglycate in young asthmittic children. Arch IDis Child 1977;52:875-6.

19. Mellon MH, Harden K, Zeiger RS. The effectiveness and safety of nebulizer cromolyn solution in the young childhood asthmatic. Immunol Altergy Pract 1982;4:168-72.

20. Geller-Bernstein C, Levin S. Sodium cromoglycate pressurized aerosol in childhood asthma. Curr Ther Res 1983;34:345-9.

21. Smith JM, Devey CF. Clinicat trial of disodiun cromoglycate in the treatment of asthma in children. BMJ 1968;2:340-4.

22. Friday GA, Facktor MA. Bernstein RA, Fireman P. Cromulyn therapy for severe asthma in children. J Pediatt 1973:83:299-304.

23. Toogood JH, Jennings B, Lelcol NM. A clinical trial of combined cromolyn/bectomethatsone treatment for chonic asthma. J Pediatr 1981;67:317-24.

24. Dawood AG, Hendry AT, Wather SR. The combined use of betitmethasone valerate and sodium cromoglycatc in the treatment of asthma. Clin Allergy 1977;7:16I-5.

25. Hiller EJ, Milner AD. Bethamethasone 17 valerate aerosol and disodium cromoglycate in severe childhood asthma. Br J Dis Chest 1975;69:103-6.

26. Selcow JE, Mendelson LM, Rosen JP. Clinical benefits of cromolyn sodium aerosol (MDI) in the treatment of asthma in children. Ann Allergy 1989:62: 195-9.

27. Lal S, Malhotra SM, Gribben MD. Comparison of sodium cromoglycate pressurized aerosol and powder in the treatment of asthma. Clin Allergy 1982;12:187-201.

28. Carrasco E, Sepulveda R. Comparison of $1 \mathrm{mg}$ and $5 \mathrm{mg}$ sodium cromoglycate metered dose inhalers in the treatment of asthma: a 12-week double-blind, purallel group trial. Curr Med Res Opin 1989;1 1:341-53.

29. Tullet WM, Tan KM, Wall RT, Paltel KR. Dose-response effect of sodium cromoglycate pressurized acrosol in exercise induced asthma. Thorax 1985;40:4 I -4.

30. Latimer KM, Roberts R, Morris MM, Hargreave FE. Inhibition by sodium cromoglycate of hronchoconstriction stimulated by respiratory heat loss: comparison of pressurized acrosol and powder. Thorax 1984:39:277-81.

31. Patel KR, Kerr JW. The dose-duration effect of sorlium cromoglycate in exercise-induced anthma. Clin Allergy 1984;14:87-91.

32. Gonzalez JP, Brogden RN. Nedocromil sodium. A preliminary review of its pharmacodynamic and pharmacokinetic properties, and therapeutic efficacy in the treatment of reversible obstructive airways disease. Drugs 1987;34:560-77.

33. Neale MG, Brown K, Foulds RA, et al. The pharmacokinetics of nedocromil sodium, a new drug for the treatment of reversible obstructive airway disease. Br J Clin Pharmacol 1987:24:493-501.

34. Eady RP, Greenwood B, Jacson DM, Orr TSC, Wells E. The effect of nedocromil sodium and sodium cromoglycate on antigen-induced bronchoconstriction in the Ascaris-sensitive monkey. Br J Pharmacol 1985:85:323-5.
35. Leung KBP, Flint KC, Brostoff J, et al. A comparison of nedocromil sodium and sodium cromoglycate on human lung mast cells obtained by bronchoalveolar lavage and by dispersion of lung tragments. Eur J Respir Dis 1986;69 (Suppl 147):223-6.

36. Wells E, Jackson CG, Harper ST, Mann J, Eady RP. Characterisation of primate bronchoalveolar mast cells. II. Inluibition of histamine, $\mathrm{LTC}_{4}$ and $\mathrm{PGD}_{2}$ release from primitc bronchoalveolar mast cells and a comparison with rat peritoneal mast cells. J Immunol 1986; 127:3941-5.

37. Moqbel R, Walsh GM, Kay AS. Inhibition of human granulotyte activation by nedocromil sodium. Eur J Respir Dis [986;69(Supp! 147):227-9.

38. Spry CJF, Kumaraswami V, Tai PC. The effect of nedocromil sodium on secretion from human eosinophils. Eur J Respir Dis 1986;69(Suppl 147):24 I-3.

39. Crimi N, Palermo F, Oliveri R, et all. Adenosine-induced bronchoconstriction: comparison between nedocromil sodium and sodium cromoglycate. Eur J Respir Dis 1986;69 (Suppl 147):258-62.

40. Bigby BG, Osborne M, Nadel J, Boushey H. Nedocromil inhibits sulfur dioxide-induced bronchoconstriction in asthmatic men. Am Rev Respir Dis 1986;133:213.

41. del Bono L, Dente FL, Patalano F, del Bono N. Protective effect of nedocromil sodium and sodium cromoglycate on bronchospasm induced by cold air. Eur J Respir Dis [986:69(Suppl 147):268-70.

42. König P, Hordvik NL, Kreutz C. The preventive effect and duration of action of nedocromil sodium and cromolyn sodium on exercise-induced asthma in adults. J Allergy Clin Immunod 1987;79:64-8.

43. Bauer CP. The protective effect of nedocromil sodium in exercise-induced asthma. Eur J Respir Dis 1986;69 (Suppl 147):252-4.

4.4. Chudry N, Correa F, Silverman M. Nedocromil sodium and exercise induced asthma. Arch Dis Child 1987:62:412-4.

45. Boner AL, Vallone G, Bennati D. Nedocromil sodium in exercise-induced bronchoonstriction in children. Ann Alkery $1989 ; 62: 39-41$

40. Dahl R, Pedersen P. Influence of nedertumil sodium on the dual asthmatic reaction after allergen challenge: a double-blind, placebo-controlled study. Eur J Respir Dis 1986;69(Suppl 147):263-5.

47. Comis A, Valletta EA, Sette L, Andreoli A, Boner AL. Comparison of nedocromil sodium and sodium cromoglycate administered by pressurized aerosol, with and without a spacer device in exercise-induced asthma. Eur Respir J 1993;6:523-6.

48. Doward AJ, Roberts JA, Thomson NC. Effect of nedocromil sodium on histamine airway responsiveness in grass-pollen sensitive asthmatics during pollen season. Clin Allergy $1986 ; 16: 3(1)-15$.

4). Altounyan REG, Cole M, Lee TB. Effects of nedocromil sodium on changes in bronchial hyperreactivity in non-asthmatic atopic rhinitic subjects during the grass pollen season. Prog Respir Res 1985;19:397-400.

50. Edwards AM, Stevens MT. The clinical efficacy of inhaled nedocromil sodium (Tilade $(B)$ in the treatment of asthma. Eur Respir J 1993;6:35-4I.

51. Bone MF, Kubik MM, Keaney NP, et al. Nedocromil sodium in adults with asthma dependent on inhaled corticosteroids: a double-blind, pliccebo controlled study. Thorax 1989:44:654-9).

52. Chadwick G, Lane DJ. A couble-hlind comparative trial of nedocromil sodium versus placebo as replacenent therapy for inhaled corticosteroids in patients with bronchiat asthma. Eur J Respir Dis 1986;69(Suppl 147):327-9.

53. Paanunen M, Karakorpi T, Kreus KE. Withdrawal ol inhaled corticosteroid under cover of nedocromil sodium. Lü J Respir Dis [ 986;69(Suppl 147):330-5. 
54. Williants AJ, Stableforth D. The atdition of nedecromil sodium to maintenince therapy in the management of pationts with bronchial asthmil. Eur J Respir Dis 1986:69 (Suppl 147):34t)-3.

55. Cirant SM, Goa KL. Fitton A, Sortin EM. Ketotilen. A review of its pharmacolynamic and pharmacokinetic properties and therapeutic use in asthma and allergic disorders. Drugs 1990;4:412-48.

56. Greenwood MI3. The phamalcology of ketotiten. Chest 1982;82(Suppl):45.

57. Martin U, Roemer D. Ketotifin, a new type of antianalphylactic agent. Allergol Immunopathol 1977;5(Suppl):5.

58. Lowe DA, Richardson BP. Effects of cyproheptadinc. ketotifen. and sodium nitroprusside on mechanical activity and calcium uptake in guinea pig Taeni coli in vitro. Respiration 1980:39(Suppl):44.

59. Amoux B. Denjean A. Page CP, el al. Accumulation of platelets and eosinophils in baboon lung after PAF-acether challenge. Am Rev Respir Dis [988:137:855-60.

60). Katy AS. Inflammatory cells in bronchial asthma. J Asthma I989:26:335-44.

61. Palmen FMLHG. Antigen bronchial challenge and efficiky after 4 weeks of treatment wilh hetotifen and disodium cromoglycate. Respiration 1983;44:103-8.

02. Lisboa C, Moreno R, Cru/ E, el ill. Acute effect of ketotifen on the dose-response curve of histamine and methatcholine in asthma. Br J Dis Chest $1985 ; 79: 235-43$.

63. Carpentiere G, Marino S. Costcllo F, Bladanza C. Bonanno CT. Effect of ketotifen on the time-course of methacholinenduced bronchoconstriction. Curr Ther Res 1989:45:107 I-6.

64. Doward AJ, Patel KR. A comparison of ketotifen with clemastine, ipratropium bromide and sodium cromoglycate in exercise-induced asthma. Clin Allergy 1982:12:355-61 .

65. Gratt-Lonnevig $V$, Hedin $G$. The effect of ketotifen on bronchial hyperreactivity in childhood asthma. J Allergy Clin Immunol 1985;76:59-6.3

60. El-Hefney A. Treatment of wheezy infants and childron with ketotifen. Pharmatherapeutica 1986:56:335-40.

67. Lopez JGH. Ketotifeno en La profilaxis del asma inlintil. Ensayo clinico controlado. Allergol Immunopathol $1985 ; 13: 1-7$.

68. Longo G, Strinati R, Poli F. Valuatuzione in duppio cieco de! chetotifene verso placebo nell'asma allergico infantile. Riv Ital Pediatria 1986;12:568-71.

69. Miraglia del Giudice M, Capristo AF, Maiello N, et al. Study of the efficacy of ketotifen treatment in asthmatic children under 3 years of age. Curr Ther Res 1986;40:685-93.

70). Gonzalez R, Girardi G. A clinical trial of ketotifen in the management of asthma in infints. Immunol Allerg Pract 1988; 10:222-6.

71. Koh YY, Choi JH, Lee BK. The effect of helolifion in the prophylaxis of bronchial asthma in children: a ciouble-blind comparison with placebo. J Korcan Soc Allerg 1988:8:215-28.

72. Neijens HJ, Knol K. Oral prophylatic treatment in wheezy infants. Immunol Allergy Prac 1988:10:17-23.

73. Naspitz CK, Friere CAR. Evaluation of ketotifen in the prophylactic treatment of bronchial atshmat in children. Allergol Immunopathol 1988; 16:27-3 I.

74. Reid JJ. Double-blind trial of ketotifen in childhood chronic cough and wheeze. Immunol Allergy Pract [989: 1 I: [4,3-50.

75. Rackham A, Brown CA. Chandra RK, ct al. A Canadian multicenter study with Zaditen (ketotifon) in the treatment of bronchial asthma in children aged 5-17 years. J Allergy Clin
Immunol 1989:84:286-96.

76. Dawson KP, Fergusson DM, Horwood LJ, Mogridge N. Ketotifen in asthma. Aust Paediatr J 1989;25:89-92.

77. Groggins RC. Hiller EJ, Milner AD, Stokes GM. Ketotilun in the prophylaxis of childhood asthmat. Arch Dis Child 1981:56:304-5.

78. Loftus BG, Price JF. Long-term, placebo-controlled trial of ketotifen in the management of preschool children with asthma. J Allergy Clin Immunol 1987;79:350-5.

79. Volovitz B, Varsanno I, Cumella JC, Jaber L. Efficacy and safety of ketotifen in young children with asthma. J Allerey Clin Immunol 1988;81:526-30.

80). White MP, MacDonald TH, Garg RA. Ketotifen in the youm asthmatic - a double-blind placebo-controlled trial. J Int Med Res 1988;16:107-13.

81. Van Asperen PP, McKay KO, Mellis CM, et al. A multicentre randomized placebo-controlled double-blind study on the efficacy of ketotifen in infants with chronic cough or wheeze. J Paediatr Child Health 1992;28:442-6.

82. Schul JF, Holgado de Cuesta D. A double-blind trial comparing disodium cromoglycate (DSCG), and ketotifen in extrinsic asthmatic children. Clin Allergy 1981;1 1:401-5.

83. Graff-Lonnevig V, Kusoffsky E. Comparison of the clinical effect of ketotifen and DSCG in pollen-induced childhood asthma. Allergy 1980;35:341-8.

84. Iikura Y, Naspiz CK, Mikawa H, et al. Prevention of asthma by ketotifen in infants with atopic dermatitis. Ann Allergy 1992;68:23-36.

85. Furukawa CT, Shapiro GG, Bierman CW, et al. A double-blint study comparing the effectiveness of cromolyn sodium and sustained releatse theophylline in childhood asthma. Pediatrics 1984;74:453-9.

80. Kraemer R, Sennhauser F, Erb K, cl al. Efficacy of regular inhalations of beclomethasone dipropionate in powder form compared to nebulized sodium cromoglycate in the control o! asthma and on bronchial hyperreactivity. Respiration 1985;46(Suppl):27

87. Shapiro CG, Furukawa CT, Pierson WE, et al. Double-blind evaluation of nebulized cromolyn, terbutaline, and the combination for childhood asthma. J Allergy Clin Immunol 1988;81:449-54.

88. Hambelton G, Weinberger M, Taylor J, et al. Comparison of cromoglycate (cromolyn) and theophylline in controlling symptoms of chronic asthma. A collaborative study. Lancet 1977;i:381-5.

89. Edmunds AT, Carswell F, Robinson P. Hughes AO). (ontrolled trial of cromoglycate and slow-release aminophylline in perennial childhood asthma. BMJ 1980;281:842.

90. Glass J, Archer LNJ, Adams W, Simpson H. Nebulized cromoglycate, theophylline, and placebo in preschool asthmatic children. Arch Dis Child 1981;56:648-51.

91. Newth CJL, Newth CV, Turner JAP. Comparison of nebulised sodium cromoglycate and oral theophylline in controlling symptoms of chronic asthma in preschool children: a doublc blind study. Aust NZ J Med 1982;12:232-8.

92. Furukawa CT, Shapiro GG, Kraemer MJ, Pierson WE, Bierman GW. A double-blind study comparing the effectiveness of cromolyn sodium and sustained-release theophylline in childhood asthma. Pediatrics 1984;74:453-9.

93. Springer C, Goldenberg B, Ben-Dov I, Godfrey S. Clinical physiology and psychologic comparison of treatment by cromolyn or theophylline in childhood asthma. J Allergy CIin Immunol 1985;76:64-9. 


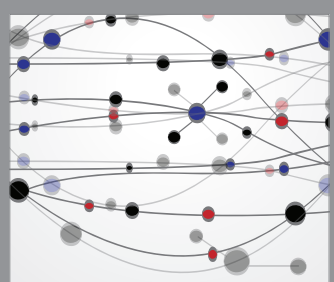

The Scientific World Journal
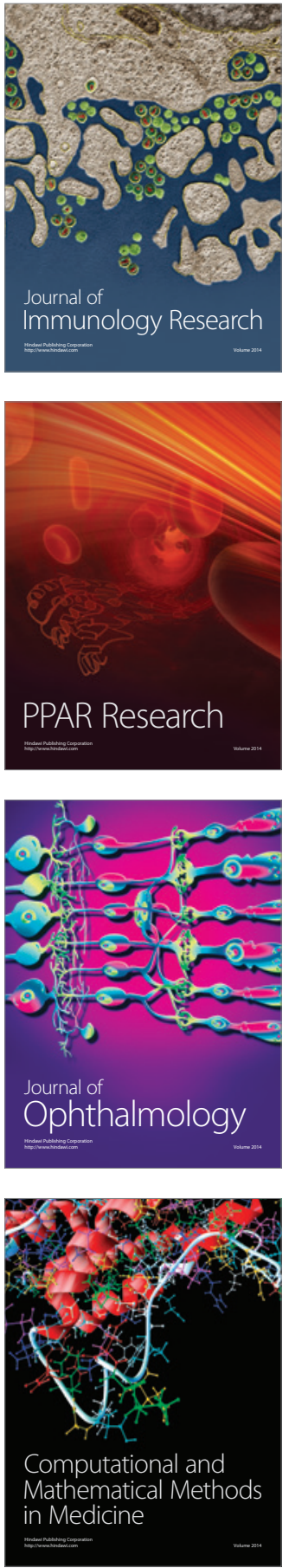

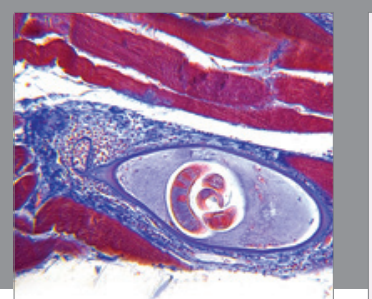

Gastroenterology Research and Practice

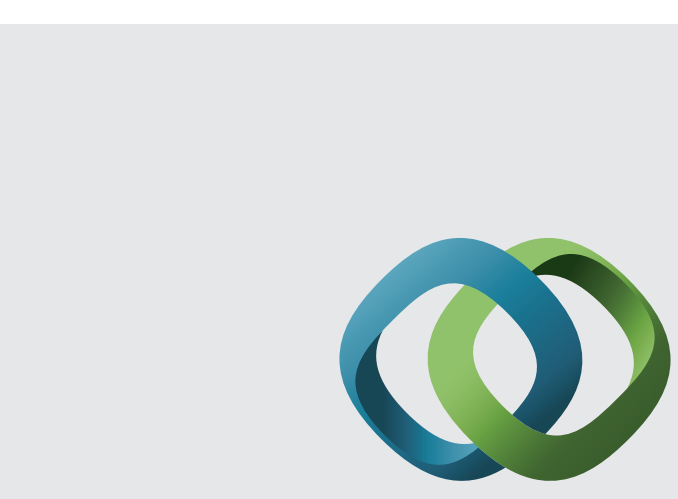

\section{Hindawi}

Submit your manuscripts at

http://www.hindawi.com
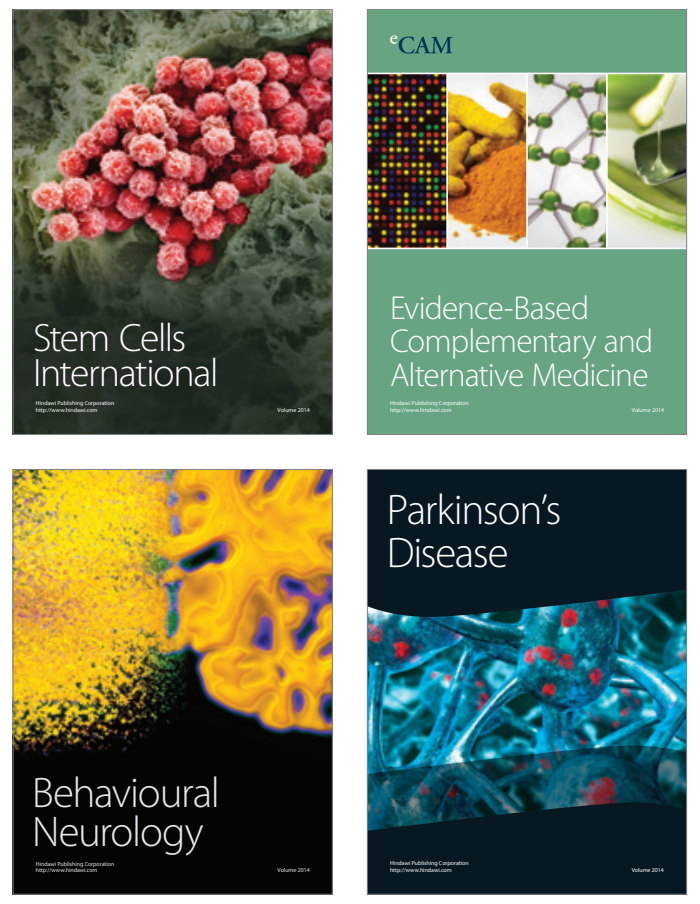
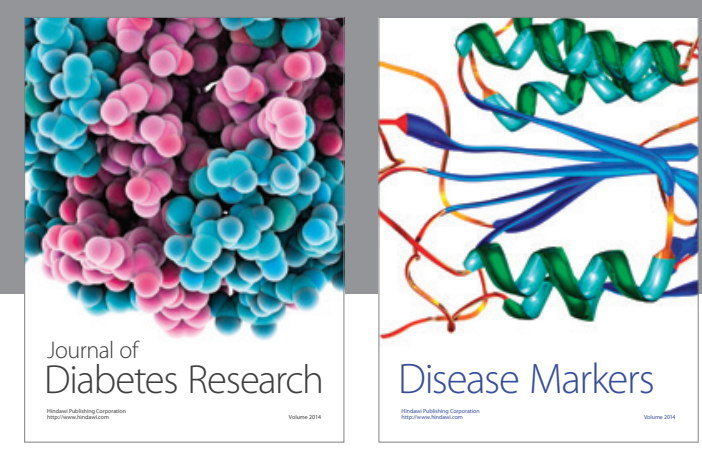

Disease Markers
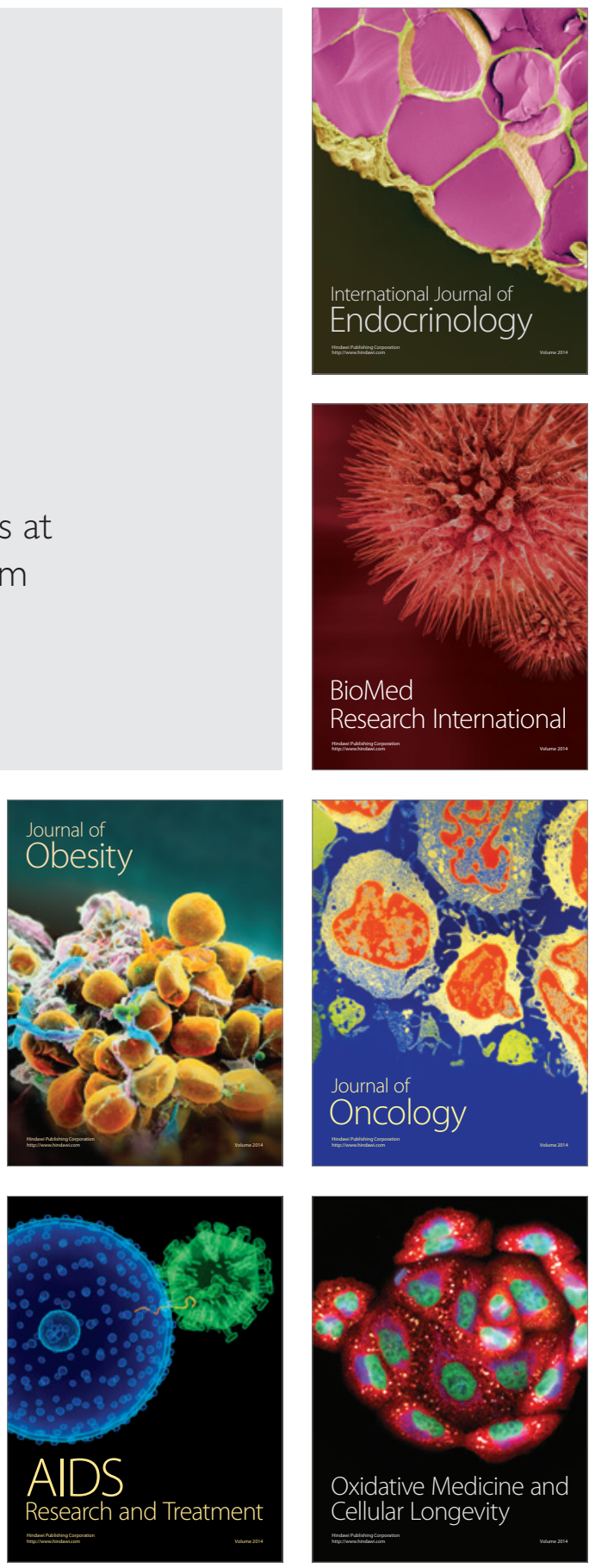